\title{
Analisis pengaruh Inflasi, Kurs Rupiah/Dolar Amerika, dan Jumlah Uang Beredar Terhadap Indeks Harga Saham Gabungan (IHSG) di Bursa Efek Indonesia Periode 2012-2016
}

\author{
Elfiswandi' ${ }^{1)}$, Alvi Hendri ${ }^{2)}$ \\ Universitas Putra Indonesia YPTK Padang \\ e-mail : elfis_wandi@yahoo.com, endri.alvi01@Gmail.com
}

\begin{abstract}
Abstrak
Tujuan penelitian adalah untuk menguji secara empiris serta menganalisis apakah ada pengaruh Inflasi, Kurs Rupiah/Dolar Amerika, dan Jumlah Uang Beredar terhadap indeks harga saham gabungan (ihsg) di Bursa Efek Indonesia. Dalam pengumpulan data, data yang digunakan berupa data sekunder yaitu data yang telah dikumpulkan oleh lembaga pengumpul data serta di publikasikan pada masyarakat pengguna data meliputi data Indeks Harga Saham Gabungan (IHSG), Inflasi, Kurs Rupiah/Dolar Amerika, Dan Jumlah Uang Beredar selama periode 2012-2016. Selain itu juga dilakukan uji asumsi klasik yang meliputi uji normalitas, uji multikolinearitas, uji heteroskedastisitas dan uji autokorelasi. Kemudian dilakukan uji hipotesis menggunakan Analisis Regresi linear berganda, menggunakan uji t untuk menguji koefisien regresi parsial, uji f untuk menguji keberartian pengaruh secara bersama-sama dengan level of significance 5\%. Serta koefesien determinasi
\end{abstract}

Keywords : Composite Stock Price Index (ihsg), inflation, Rupiah / US dollar.

\section{PENDAHULUAN}

Pasar modal menjadi sesuatu yang penting dan sangat berharga. Pernyataan ini bisa benar kalau menyimak globalisasi didunia keuangan dimana pasar modal adalah ujung yang paling awal tersentuh globalisasi ini dan membayangkan manfaat yang dapat dipetik dari bebasnya modal bergerak akibat globalisasi itu. Negara miskin, misalnya, kalau mampu memberi return yang tinggi tetap akan mendapatkan aliran modal. Globalisasi terutama pasar uang dan pasar modal merupakan simbol kemordern nan. Globalisai sudah merupakan kebutuhan. Akan tetapi pasar modal merupakan salah satu alat penggerak perekonomian di suatu negara, karena pasar modal merupakan sarana pembentuk modal dan akumulasi dana jangka panjang yang diarahkan untuk meningkatkan partisipasi masyarakat dalam penggerakan dana guna menunjang pembiayaan pembangunan nasional. Selain itu, pasar modal juga merupakan representasi untuk menilai kondisi perusahaan di suatu negara, karena hampir semua industri di suatu Negara terwakili oleh pasar modal.

Pasar modal yang mengalami peningkatan (bullish) atau mengalami penurunan (bearish) terlihat dari naik turunnya harga harga saham yang tercatat yang tercermin melalui suatu pergerakan indeks atau lebih dikenal dengan Indeks Harga Saham Gabungan (IHSG). IHSG merupakan Indeks yang merangkum perkembangan harga-harga saham di BEI ( Bursa Efek Indonesia ) Menurut Widoatmodjo (2015). IHSG merupakan nilai yang digunakan untuk mengukur kinerja gabungan seluruh saham (perusahaan/emiten) yang tercatat di Bursa Efek Indonesia (BEI).

Inflasi merupakan kecenderungan terjadinya kenaikan harga produk secara keseluruhan, sehingga menaikkan pendapatan dan biaya perusahaan. Kenaikan biaya produksi yang lebih besar daripada kenaikan harga akan mengakibatkan keuntungan investor dan return investasi menurun sehingga investasi kurang menarik akibatnya harga saham akan menurun. Inflasi yang tinggi biasanya dikaitkan dengan kondisi ekonomi yang terlalu panas (overheated). Artinya, kondisi ekonomi mengalami permintaan ats produk yang melebihi kapasitas penawaran produkya, sehingga harga-harga cendrung mengalami kenaikan. Inflasi yang terlalu tinggi juga akan menyebabkan penurunan daya beli uang (purchasing power of money).

Kurs merupakan nilai tukar mata uang suatu negara dan dalam sistem perekonomiaan manapun sangat sulit untuk mempertahankan kestabilan nilai tukar mata uang tersebut. Tetapi disisi lain penguatan nilai tukar mata uang suatu negara bisa menekan laju inflasi. Kurs valuta asing adalah salah satu alat pengukur lain yang digunakan dalam menilai kekuatan suatu perekonomian. Kurs 
menunjukkan banyaknya uang dalam negeri yang diperlukan untuk membeli satu unit valuta asing tertentu.Kurs valuta asing dapat dipandang sebagai harga dari suatu mata uang asing.Salah satu faktor penting yang mempengaruhi kurs valuta asing adalah neraca perdagangan nasional.Neraca perdagangan nasional yang mengalami defisit cenderung untuk menaikkan nilai valuta asing. Dan sebaliknya, apabila neraca pembayaran kuat (surplus dalam neraca keseluruhan) dan cadangan valuta asing yang dimiliki negara terus menerus bertambah jumlahnya, nilai valuta asing akan bertambah murah..Apabila harga barang dan sektor jasa cenderung mengalami kenaikan maka disebut dengan inflasi. Oleh sebab itu untuk mencegah makin meningkatnya inflasi maka jumlah mata uang yang beredar harus sesuai dengan kebutuhan, sehingga kestabilan nilai tukar dijaga ( permintaan agregat ).

\section{Rumusan Masalah}

Adapun rumusan masalah dari penelitian ini adalah sebagai berikut:

1. Apakah terdapat pengaruh Inflasi terhadap Indeks Harga Saham Gabungan di Bursa Efek Indonesia.

2. Apakah terdapat pengaruh Kurs Rupiah/Dolar Amerika terhadap Indeks Harga Saham Gabungan di Bursa Efek Indonesia.

3. Apakah terdapat pengaruh Jumlah Uang Beredar terhadap Indeks Harga Saham Gabungan di Bursa Efek Indonesia.

4. Apakah terdapat pengaruh Inflasi, Kurs Rupiah/Dolar Amerika dan Jumlah Uang Beredar terhadap Indeks Harga Saham Gabungan di Bursa Efek Indonesia.

\section{TINAJUAN TEORI}

\section{Indeks Harga Saham Gabungan}

Menurut anoraga dalam fildria (2014:26) Indeks Harga Saham Gabungan adalah suatu nilai yang digunakan untuk mengukur kinerja saham yang tercatat disuatu bursa efek. Indeks harga saham ini ada yang dikeluarkan dibursa efek yang bersangkutan secara resmi da nada juga yang dikeluarkan instuisi tertentu seperti media massa keuangan, media elektronik dan instuisi keuangan lainnya, maka gabungan pada IHSG yaitu menggambarkan kinerja saham semua perusahaan yang listing. Bursa Efek Indonesia tidak bertanggung jawab atas produk yang diterbitkan oleh pengguna yang mempergunakan IHSG sebagai acuan (benchmark). Bursa Efek Indonesia juga tidak bertanggung jawab dalam bentuk apapun atas keputusan investasi yang dilakukan oleh siapapun pihak yang menggunakan IHSG sebagai acuan (benchmark).

\section{Jenis-jenis Indeks Saham}

Indeks harga saham dalam situs www.bi,go.id adalah suatu indikator yang menunjukkan pergerakan harga saham. Indeks berfungsi sebagai indikator tren pasar, artinya pergerakan indeks menggambarkan kondisi pasar pada saat pasar sedang aktif maupun sedang dalam kondisi lesu. Pergerakan nilai indeks akan menunjukan perubahan situasi pasar yang terjadi, pasar yang sedang positif atau terjadi transaksi yang aktif, ditunjukkan dengan indeks harga saham yang mengalami kenaikan.

1. Indeks Harga Saham Gabungan (IHSG)

Menggunakan semua Perusahaan Tercatat sebagai komponen perhitungan Indeks. Agar IHSG dapat menggambarkan keadaan pasar yang wajar, Bursa Efek Indonesia berwenang mengeluarkan dan atau tidak memasukkan satu atau beberapa perusahaan tercatat dari perhitungan IHSG. Dasar pertimbangannya antara lain, jika jumlah saham perusahaan tercatat tersebut yang dimiliki oleh publik (free float) relatif kecil sementara kapitalisasi pasarnya cukup besar, sehingga perubahan harga saham perusahaan tercatat tersebut berpotensi mempengaruhi kewajaran pergerakan IHSG. 


\section{Indeks Sektoral}

Menggunakan semua perusahaan tercatat yang termasuk dalam masing-masing sektor. Sekarang ini ada 10 sektor yang ada di BEI yaitu sektor pertanian, pertambangan, industri dasar, aneka industri, barang konsumsi, properti, infrastruktur, keuangan, perdangangan dan jasa, dan manufaktur.

\section{Indeks LQ45}

Indeks yang terdiri dari 45 saham perusahaan tercatat yang dipilih berdasarkan pertimbangan likuiditas dan kapitalisasi pasar, dengan kriteria-kriteria yang sudah ditentukan. Review dan penggantian saham dilakukan setiap 6 bulan.

4. Jakarta Islamic Index (JII)

Indeks yang menggunakan 30 saham yang dipilih dari saham-saham yang masuk dalam kriteria syariah (Daftar Efek Syariah yang diterbitkan oleh Bap Menggunakan semua Perusahaan Tercatat sebagai komponen perhitungan Indeks. Agar IHSG dapat menggambarkan keadaan pasar yang wajar, Bursa Efek Indonesia berwenang mengeluarkan dan atau tidak memasukkan satu atau beberapa perusahaan tercatat dari perhitungan IHSG. epam-LK) dengan mempertimbangkan kapitalisasi pasar dan likuiditas.

5. Indeks Kompas 100

Indeks yang terdiri dari 100 saham perusahaan tercatat yang dipilih berdasarkan pertimbangan likuiditas dan kapitalisasi pasar, dengan kriteria-kriteria yang sudah ditentukan. Review dan penggantian saham dilakukan setiap 6 bulan.

6. Indeks BISNIS-27

Kerja sama antara Bursa Efek Indonesia dengan harian bisnis Indonesia meluncurkan indeks harga saham yang diberi nama Indeks BISNIS-27. Indeks yang terdiri dari 27 saham perusahaan tercatat yang dipilih berdasarkan kriteria fundamental, teknikal atau likuiditas transaksi dan akuntabilitas dan tata kelola perusahaan.

7. Indeks PEFINDO25

Kerja sama antara Bursa Efek Indonesia dengan lembaga rating PEFINDO meluncurkan indeks harga saham yang diberi nama Indeks PEFINDO25. Indeks ini dimaksudkan untuk memberikan tambahan informasi bagi pemodal khususnya untuk saham-saham emiten kecil dan menengah (Small Medium Enterprises / SME). Indeks ini terdiri dari 25 saham perusahaan tercatat yang dipilih dengan mempertimbangkan kriteria-kriteria seperti: Total Aset, tingkat pengembalian modal (Return on Equity / ROE) dan opini akuntan publik. Selain kriteria tersebut di atas, diperhatikan juga factor likuiditas dan jumlah saham yang dimiliki publik.

8. Indeks SRI-KEHATI

Indeks ini dibentuk atas kerja sama antara Bursa Efek Indonesia dengan Yayasan Keanekaragaman Hayati Indonesia (KEHATI). SRI adalah kependekan dari Sustainable Responsible Investment. Indeks ini diharapkan memberi tambahan informasi kepada investor yang ingin berinvestasi pada emiten-emiten yang memiliki kinerja sangat baik dalam mendorong usaha berkelanjutan, serta memiliki kesadaran terhadap lingkungan dan menjalankan tata kelola perusahaan yang baik. Indeks ini terdiri dari 25 saham perusahaan tercatat yang dipilih dengan mempertimbangkan kriteri-kriteria seperti: Total Aset, Price Earning Ratio(PER) dan Free Float.

9. Indeks Papan Utama

Menggunakan saham-saham perusahaan tercatat yang masuk dalam papan utama.

10.Indeks Papan Pengembangan

Menggunakan saham-saham perusahaan tercatat yang masuk dalam papan pengembangan.

11.Indeks Individual

Indeks harga saham masing-masing perusahaan tercatat. Dimana menggunakan indeks harga masing-masing saham terhadap harga dasarnya.

Seluruh indeks yang terdapat di BEI menggunakan metode perhitungan yang sama, yaitu metode rata-rata tertimbang berdasarkan jumlah saham tercatat sebagai komponen perhitungan. Perbedaan utama pada masing-masing indeks adalah jumlah emiten dan nilai dasar yang digunakan untuk penghitungan indeks. Misalnya untuk Indeks LQ45 menggunakan 45 emiten untuk perhitungan indeks sedangkan Jakarta Islamic Index (JII) menggunakan 30 emiten 


\section{Inflasi}

\section{Pengertian Inflasi}

Pengertian inflasi menurut Latumaerissa (2012:22) inflasi merupakan kecenderungan dari harga-harga untuk menaik secara terus menerus. Dari defenisi ini ada tiga komponen yang harus dipenuhi agar dapat dikatakan telah terjadi inflasi:

1. Kenaikan harga

Harga suatu komoditas dikatakan naik jika menjadi lebih tinggi dari pada harga periode sebelumnya. Dan kenaikan harga semacam ini tidak dianggap sebagai suatu "penyakit ekonomi" yang memerlukan penangan khusus untuk menanggulanginya.

2. Bersifat umum

Suatu kondisi dapat dikatakan inflasi jika kenaikan tersebut menyebabkan harga-harga secara umum naik. Pengalaman indonesia, menunjukkan setiap pemerintah menaikan harga BBM, harga komoditas lain juga ikut naik. Karena BBM merupakan komoditas strategis, maka kenaikan BBM akan merambat kepada kenaikan harga komoditas yang lain.

3. Berlangsung terus menerus

Kenaikan harga yang bersifat umum tersebut terjadi tidak hanya sesaat tetapi terus menerus.Oleh sebab itu perhitungan inflasi dilakukan dalam rentang waktu minimal bulanan. Sebab dalam sebulan akan terlihat apakah kenaikan harga bersifat umum dan terus menerus. Rentang waktu yang lebih panjang adalah triwulan dan tahunan.

\section{Teori Inflasi}

Dari sumber http://skul-id.blogspot.co.id/2016/07/3-teori-inflasi-teori-kuantitas-teori.html.

Berikut ini mengemukakan bahwa teori inflasi terdiri dari:

1. Teori kuantitas

Teori ini adalah teori tertua yang membahas tentang inflasi.Teori ini menekankan pada peranan proses inflasi dari jumlah uang beredar dan psikologi (harapan) masyarakat mengenai kenaikan harga-harga (expectation). Berdasarkan teori ini ada 2 faktor yang menyebabkan inflasi:

a. Jumlah uang yang beredar

Semakin besar jumlah uang yang beredar dalam masyarakat maka inflasi juga akan meningkat. Oleh karena itu sebaiknya pemerintah harus memperhitungkan atau memperkirakan akan timbulnya inflasi yang bakal terjadi bila ingin mengadakan penambahan pencetakan uang baru, karena pencetakan uang baru yang terlalu besar akan mengakibatkan goncangnya perekonomian.

b. Perkiraan/anggapan masyarakat

Bahwa harga-harga akan naik Jika masyarakat beranggapan harga-harga akan naik maka tidak ada kecenderungan untuk menyimpan uang tunai lagi, masyarakat akan menyimpan uang mereka dalam bentuk barang sehingga permintaan akan mengalami peningkatan. Hal ini mendorong naiknya harga secara terus-menerus.

Cara mengatasi inflasi menurut teori kuantitas ini juga hanya ada satu jalan saja yang merupakan kunci untuk menghilangkan inflasi yaitu dengan mengurangi jumlah uang yang beredar. Maksudnya bahwa terjadinya inflasi entah faktor apapun yang menyebabkannya, asal jumlah uang yang beredar dikurangi maka dengan sendirinya inflasi akan hilang dan harga akan kembali pada tingkat yang wajar.

2. Teori keynes

Menurut teori ini inflasi terjadi karena masyarakat memiliki permintaan melebihi jumlah uang yang tersedia. Dalam teorinya, Keynes menyatakan bahwa inflasi terjadi karena masyarakat ingin hidup melebihi batas kemampuan ekonomisnya. Proses perebutan rezeki antargolongan masyarakat masih menimbulkan permintaan agregat (keseluruhan) yang lebih besar daripada 
jumlah barang yang tersedia, mengakibatkan harga secara umum naik. Jika hal ini terus terjadi maka selama itu pula proses inflasi akan berlangsung. Yang dimaksud dengan golongan masyarakat di sini adalah:

a. Pemerintah, yang melakukan pencetakan uang baru untuk menutup defisit anggaran belanja dan belanja negara ;

b. Pengusaha swasta, yang menambah investasi baru dengan kredit yang mereka peroleh dari bank;

c. Pekerja/serikat buruh, yang menuntut kenaikan upah melebihi pertambahan produktivitas.

Tidak semua golongan masyarakat berhasil memperoleh tambahan dana, karena penghasilan mereka rata-rata tetap dan tidak bisa mengikuti laju inflasi, misalnya pegawai negeri, pensiunan dan petani.

3. Teori strukturalis

Teori Strukturalis disebut juga dengan teori inflasi jangka panjang karena menyoroti sebab inflasi yang berasal dari struktur ekonomi, khususnya supply bahan makanan dan barang ekspor. Pertambahan produksi barang tidak sebanding dengan pertumbuhan kebutuhannya, akibatnya terjadi kenaikan harga bahan makanan dan kelangkaan devisa. Selanjutnya adalah kenaikan harga barang yang merata sehingga terjadi inflasi. Inflasi semacam ini tidak bisa diatasi hanya dengan mengurangi jumlah uang yang beredar, tetapi harus diatasi dengan peningkatan produktivitas dan pembangunan sektor bahan makanan dan barang-barang ekspor.

\section{Macam-macam Inflasi}

Menurut Latumaerissa (2012:24) ada beberapa macam inflasi diantaranya ialah sebagai berikut:

a. Menurut tingkat keparahan atau laju inflasi, meliputi:

1. Inflasi ringan yaitu inflasi yang tingkatannya masih dibawah $10 \%$ setahun.

2. Inflasi sedang yaitu inflasi yang tingkatannya berada antara $10 \%-30 \%$ setahun.

3. Inflasi berat yaitu inflasi yang tingkatnya berada diantara $30 \%-100 \%$ setahun.

4. Hiper inflasi yaitu inflasi yang tingkat keparahan nya berada diatas $100 \%$ setahun.

Inflasi parah yang dialami oleh Indonesia adalah sejak tahun 1963 sampai dengan tahun 1966 diangka lebih dari $150 \%$ bahkan pernah mencapai tepatnya pada tahun 1966 yaitu menjadi $635 \%$. Itu terjadi pada masa orde lama, dan ketika pada masa orde baru dapat berhasil menekan inflasi.Menurut penyebab awal inflasi

1. Demand pull inflation yaitu inflasi yang menyebabkan karena permintaan masyarakat akan berbagai barang terlalu kuat

2. Cost push inflation, inflasi yang timbul karena kenaikan ongkos produksi secara terus menerus

3. Inflasi permintaan dan penawaran inflasi ini disebabkan kenaikan dan permintaan di satu sisi dan penawan disisi lain.

b. Didasarkan pada asas inflasi

1. Domestic inflation atau inflasi yang berasal dari dalam negeri. Inflasi ini terjadi karena defisit anggaran belanja yang dibiayai dengan pencetakan uang baru, panen yang gagal dan sebagainya.

2. Imported inflation atau inflasi yang tertular dari luar negeri. Inflasi ini di sebabkan kenaikan barang-barang exspor seperti teh dan kopi diluar negeri ( negara tujuan ekspor), harga mengalami kenaikan dan ini membawa pengaruh terhadap harga didalam negeri.

\section{Jumlah Uang Beredar \\ Pengertian Jumlah Uang Beredar}

Menurut Boediono dalam Kusharfitri (2016) Definisi uang beredar terdiri dari dua bagian yaitu :Pertama, uang beredar dalam arti sempit (narrow money) merupakan seluruh "uang kartal" dan "uang giral" yang tersedia untuk digunakan oleh masyarakat. Uang kartal adalah uang tunai yang 
dikeluarkan oleh pemerintah atau bank sentral yang langsung dibawah kekuasaan masyarakat (umum) untuk menggunakannya. Uang giral adalah seluruh nilai saldo rekening koran (giro) yang dimiliki masyarakat pada bank-bank umum. Saldo ini merupakan bagian dari "uang yang beredar" karena sewaktu-waktu bisa digunakan oleh pemiliknya (masyarakat) untuk kebutuhannya (transaksi, berjaga-jaga, spekulasi), persis seperti halnya uang kartal. Saldo rekening koran (giro) milik suatu bank lain bukan uang giral. Jumlah uang beredar pada suatu saat adalah penjumlahan dari uang kartal dan uang giral.

\section{Faktor-Faktor Yang Mempengaruhi Terhadap Jumlah Uang Yang Beredar}

Darisumberhttp://ayuapriliani46.blogspot.co.id/2017/03/ekonomi-moneter-jumlah-uangberedar.html. Di dalam kehidupan masyarakat, jumlah uang yang beredar ditentukan oleh kebijakan dari bank sentral untuk menambah atau mengurangi jumlah uang melalui kebijakan moneter. Adapun faktor-faktor yang mempengaruhi jumlah uang yang beredar adalah:

1. Kebijakan Bank Sentral berupa hak otonom dan kebijakan moneter (meliputi: politik diskonto, politik pasar terbuka, politik cash ratio, politik kredit selektif) dalam mencetak dan mengedarkan uang kartal.

2. Kebijakan pemerintah melalui menteri keuangan untuk menambah peredaran uang dengan cara mencetak uang logam dan uang kertas yang nominalnya kecil.

3. Bank umum dapat menciptakan uang giral melalui pembelian saham dan surat berharga.

4. Tingkat pendapatan masyarakat

5. Tingkat suku bunga bank

6. Selera konsumen terhadap suatu barang (semakin tinggi selera konsumen terhadap suatu barang maka harga barang tersebut akan terdorong naik, sehingga akan mendorong jumlah uang yang beredar semakin banyak, demikian sebaliknya)

7. Harga barang

8. Kebijakan kredit dari pemerintah Dari beberapa faktor yang mempengaruhi jumlah uang yang beredar di masyarakat, maka kita dapat melihat hal apa saja yang mempengaruhi permintaan uang, yaitu:

1. Besar kecilnya pembelanjaan negara yang berkaitan dengan pendapatan nasional.

2. Cepat lambatnya laju peredaran uang

3. Motif memiliki uang tunai, J.M Keynes dalam teori liquidity preference: motif transaksi (transaction motive), motif berjaga-jaga (precautionary motive), motif spekulasi (speculative motive)

Bila ada hal yang mempengaruhi permintaan uang, berarti ada hal yang mempengaruhi penawaran uang juga, yaitu:

1. tinggi rendahnya tingkat bunga

2. tingkat pendapatan masyarakat

3. jumlah penduduk

4. keadaan letak geografis

5. struktur ekonomi masyarakat

6. penguasaan iptek

7. globalisasi ekonomi

\section{Kerangka pikir:}

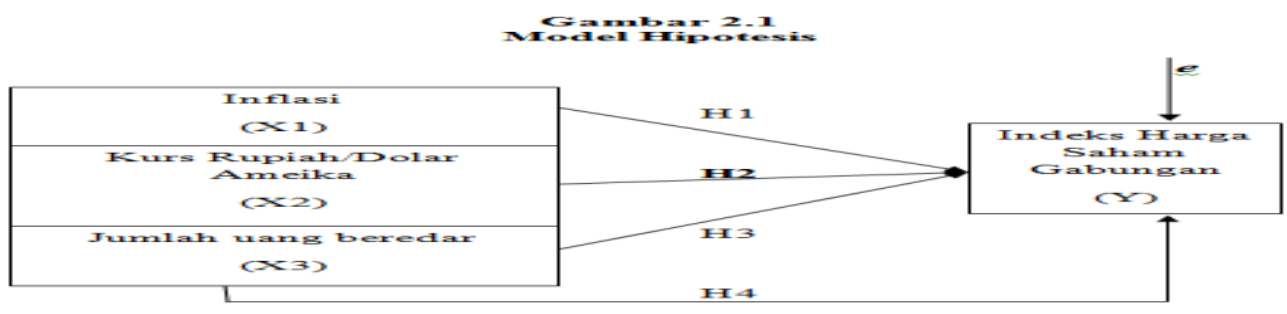




\section{Hipotesa}

H1. Diduga Inflasi berpengaruh signifikan terhadap Indeks Harga Saham Gabungan di Bursa Efek Indonesia

H2. Diduga Kurs Rupiah/Dolar Amerika berpengaruh signifikan terhadap Indeks Harga Saham Gabungan di Bursa Efek Indonesia.

H3. Diduga jumlah uang beredar berpengaruh signifikan terhadap Indeks Harga Saham Gabungan di Bursa Efek Indonesia.

H4. Diduga Inflasi, Kurs Rupiah/Dolar Amerika, dan Jumlah Uang Beredar berpengaruh signifikan secara bersama-sama terhadap Indeks Harga Saham Gabungan di Bursa Efek Indonesia.

\section{METODELOGI PENELITIAN}

\section{Metode Analisis Data}

Dalam penelitian ini, pengolahan data dilakukan dengan program Eviews Enterprise Edition V8.0.0.1. Data yang digunakan dalam penelitian ini adalah Inflasi, Kurs Rupiah/Dolar Amerika dan Jumlah Uang Beredar. Serta Indeks Harga Saham Gabungan secara bulanan dari tahun 2012-2016.

\section{Uji Regresi Linear Berganda}

Uji regresi linear berganda untuk menguji apakah variabel independen berpengaruh terhadap variabel dependen, baik secara parsial maupun simultan. Regresi linier mengestimasikan besarnya koefisien-koefisien yang dihasilkan dari persamaan yang bersifat linier, yang melibatkan satu variabel bebas, untuk digunakan sebagai alat prediksi besarnya nilai variabel.

Persamaan Regresi Linear Berganda

$\mathrm{IHSG}=\alpha+\mathrm{b}_{1} \operatorname{Inf}+\mathrm{b}_{2} \mathrm{KRDA}+\mathrm{b}_{3} \mathrm{JUB}+\mathrm{e}$

Dimana :

IHSG $\quad=$ Variabel dependen $($ IHSG)

Inf $\quad=$ Inflasi

KRDA $\quad=$ Kurs Rupiah/Dolar Amerika

JUB = Jumlah uang beredar

$\alpha \quad=$ Konstanta

$\mathrm{b}_{2} \mathrm{~b}_{2} \quad=$ Koefisien regresi (nilai peningkatan atau penurunan)

$\mathrm{e} \quad=$ Kesalahan pengganggu

\section{Metode Pengujian Hipotesis}

Uji Signifikan Parsial (Uji-t)

Uji-t dilakukan untuk mengetahui signifikan tidaknya pengaruh masing-masing variabel bebas terhadap variabel terikat, atau dengan kata lain untuk menguji pengaruh variabel independen dan variabel dependen secara parsial. Uji ini dilakukan dengan membandingkan t-hitung dengan t-tabel dengan ketentuan sebagai berikut:

1) Apabila probabilitas thitung $<0,05$, maka Ho ditolak dan Ha diterima

2) Apabila probabilitas thitung $>0,05$, maka Ho diterima dan Ha ditolak

\section{Uji Signifikan Simultan (Uji-F)}

Uji-F dilakukan untuk menunjukkan apakah semua variabel independen mempunyai pengaruh secara bersama-sama terhadap variabel dependen.

Bentuk pengujiannya:

a. Ho : $\mathrm{b} 1=\mathrm{b} 2=0$, artinya semua variabel independen secara simultan tidak berpengaruh terhadap variabel dependen

b. Ho : $b 1 \neq b 2 \neq 0$, artinya semua variabel independen berpengaruh secara simultan

Uji ini dilakukan dengan membandingkan signifikansi F-hitung dengan F-tabel dengan ketentuan: 
a. Bila $\mathrm{F}$ hitung < F tabel ; maka variabel bebas secara serentak tidak berpengaruh terhadap variabel dependen.

b. Bila F hitung > F tabel; maka variabel bebas secara serentak berpengaruh terhadap variabel dependen.

\section{Uji Koefisien Determinasi}

Koefisien Determinasi $\left(\mathrm{R}^{2}\right)$ dimaksudkan untuk mengetahui tingkat ketepatan paling baik dalam analisis regresi dimana hal yang ditunjukkan oleh besarnya koefisien determinasi $\left(\mathrm{R}^{2}\right)$ antara 0 (nol) sampai 1 (satu). Koefisien determinasi nol, variabel independen sama sekali tidak berpengaruh terhadap variabel dependen. Apabila koefisien determinasi semakin mendekati satu, maka dapat dikatakan bahwa variabel independen berpengaruh terhadap variabel dependen, selain itu koefisien determinasi digunakan untuk mengetahui persentase perubahan variabel tidak bebas (Y) yang disebabkan oleh variabel bebas $(\mathrm{X})$.

\section{HASIL DAN PEMBAHASAN}

\begin{tabular}{|c|c|c|c|c|}
\hline \multicolumn{5}{|c|}{$\begin{array}{l}\text { Dependent Variable: IHSG } \\
\text { Method: Least Squares } \\
\text { Date: } 01 / 10 / 18 \text { Time: } 21: 36 \\
\text { Sample: } 1 \text { 60 } \\
\text { Included observations: } 60\end{array}$} \\
\hline Variable & Coefficient & Std. Error & t-Statistic & Prob. \\
\hline $\begin{array}{c}\text { INFIASI } \\
\text { KUTRS } \\
\text { JUB }\end{array}$ & $\begin{array}{r}-47995.57 \\
83.34226 \\
-5875.038 \\
7073.832\end{array}$ & $\begin{array}{l}5053.359 \\
23.62752 \\
964.1226 \\
874.5601\end{array}$ & $\begin{array}{r}-9.497755 \\
3.527339 \\
-6.093663 \\
8.088446\end{array}$ & $\begin{array}{l}0.0000 \\
0.0008 \\
0.0000 \\
0.0000\end{array}$ \\
\hline $\begin{array}{l}\text { R-squared } \\
\text { Adjusted R-squared } \\
\text { S.E. of regression } \\
\text { Sum squared resid } \\
\text { Log likelihood } \\
\text { F-statistic } \\
\text { Prob(F-statistic) }\end{array}$ & $\begin{array}{l}0.683076 \\
0.666098 \\
258.0133 \\
3727967 \\
-416.2472 \\
40.23288 \\
0.000000\end{array}$ & $\begin{array}{l}\text { Mean depend } \\
\text { S.D.depende } \\
\text { Akaike infoc } \\
\text { Schwarz crite } \\
\text { Hannan-Quin } \\
\text { Durbin-Wrats }\end{array}$ & r & $\begin{array}{l}4719.526 \\
446.5115 \\
14.00824 \\
14.14786 \\
14.06285 \\
0.502627\end{array}$ \\
\hline
\end{tabular}

Model analisis regresi berganda yang digunakan dalam penelitian ini dapat dirumuskan sebagai berikut:

$$
\text { IHSG }=-47995.569+83.342 * \text { INFLASI 5875.038*KURS + 7073.831 } * \text { JUB + e }
$$

Dari persamaan regresi tersebut dapat diungkapkan:

\section{Konstanta}

Nilai konstanta yang diperoleh sebesar $-47995,569$ yang berarti hal ini menandakan adanya pengaruh variabel Inflasi, Kurs Rupiah/Dolar Amerika dan Jumlah Uang Beredar akan terjadi nilai konstanta pada Indeks Harga Saham Gabungan sebesar -47995,569

2. Regresi X1

Nilai koefisien regresi variabel inflasi menunjukkan angka 83,342 mempunyai arti bahwa jika kurs rupiah/dolar amerika dan jumlah uang beredar konstan maka setiap peningkatan inflasi sebesar 1 satuan akan menurunkan indeks harga saham gabungan sebesar 83,342 satuan.

3. Regresi X2

Nilai koefisien regresi variabel Kurs Rupiah/Dolar Amerika menunjukkan angka -5875,038 mempunyai arti bahwa jika Inflasi dan Jumlah Uang Beredar konstan maka setiap peningkatan kurs sebesar 1 satuan akan menurunkan Indeks Harga Saham Gabungan sebesar $-5875,038$ satuan.

4. Regresi X3 
Nilai koefisien regresi variabel Jumlah uang beredar menujukkan angka 7073,831 mempunyai arti bahwa jika Inflasi dan Kurs Rupiah/Dolar Amerika konstan maka setiap peningkatan Jumlah Uang Beredar sebesar 1 satuan akan menurunkan Indeks Harga Saham Gabungan sebesar 7073,831 satuan.

\section{Uji Hipotesis}

\section{Hasil Pengujian Hipotesis Secara Parsial (Uji t)}

Uji t digunakan untuk menguji pengaruh variabel independen secara parsial terhadap variabel dependen. Pengujian ini dilakukan dengan ketentuan :

1) Apabila probabilitas thitung $<0,05$, maka Ho ditolak dan Ha diterima

2) Apabila probabilitas thitung $>0,05$, maka Ho diterima dan Ha ditolak

Dan menunjukkan seberapa jauh pengaruh masing-masing variabel independent secara individu dalam menerangkan variasi variabel dependen.

Hasil pengujian $\mathrm{T}$ dapat dilihat pada tabel 4.8 dengan penjelasan:

\begin{tabular}{|c|c|c|c|c|}
\hline \multicolumn{5}{|c|}{$\begin{array}{l}\text { Dependent Variable: IHSG } \\
\text { Method:Ieast Squares } \\
\text { Date: } 01 / 10 / 18 \text { Time: } 21: 36 \\
\text { Sample: } 1 \text { 60 } \\
\text { Included observations: } 60\end{array}$} \\
\hline Variable & Coefficient & Std. Error & t-Statistic & Prob. \\
\hline $\begin{array}{c}\text { INFIASI } \\
\text { KURS } \\
\text { JUB }\end{array}$ & $\begin{array}{r}-47995.57 \\
83.34226 \\
-5875.038 \\
7073.832 \\
\end{array}$ & $\begin{array}{l}5053.359 \\
23.62752 \\
964.1226 \\
874.5601\end{array}$ & $\begin{array}{r}-9.497755 \\
3.527339 \\
-6.093663 \\
8.088446\end{array}$ & $\begin{array}{l}\text { O. }-0000 \\
\text { O.0000 } \\
\text { O.0000 } \\
\text { O.0000 }\end{array}$ \\
\hline $\begin{array}{l}\text { R-squared } \\
\text { Adjusted R-squared } \\
\text { S.E. ofregression } \\
\text { Sum squared resid } \\
\text { Iog likelihood } \\
\text { F-statistic } \\
\text { Prob(F-statistic) }\end{array}$ & $\begin{array}{l}0.683076 \\
0.666098 \\
258.0133 \\
3727967 . \\
-416.2472 \\
40.23288 \\
0.000000\end{array}$ & $\begin{array}{l}\text { Mean depend } \\
\text { S.D.depende } \\
\text { Akaike infod } \\
\text { Schwarz crite } \\
\text { Hannan-Quin } \\
\text { Durbin-Vits }\end{array}$ & er & $\begin{array}{l}4719.526 \\
446.5115 \\
14.00824 \\
14.14786 \\
14.06285 \\
0.502627\end{array}$ \\
\hline
\end{tabular}

1. Pengujian Hipotesis Pertama

Hasil analisis menunjukkan bahwa dapat diketahui Inflasi menghasilkan nilai t-statistic sebesar 3,527339. Variabel ini mempunyai pengaruh positif dan tingkat signifikan probability sebesar 0,0008 yang apabila dibandingkan dengan derajat kesalahan yang telah di tentukan sebesar 5\%, variabel ini termasuk signifikan. Nilai signifikan variabel lebih kecil dari derajat kesalahan $(0,0008<0,05)$ yang artinya bahwa hipotesis 0 ditolak dan $\mathrm{H} 2$ diterima. Dari hasil uji t disimpulkan bahwa inflasi berpengaruh positif dan signifikan terhadap Indeks Harga Saham Gabungan (IHSG).

2. Pengujian Hipotesis Kedua

Hasil analisis menunjukkan bahwa dapat diketahui Kurs Rupiah/Dolar Amerika menghasilkan nilai t-statistic sebesar -6.093663 bahwa kurs mempunyai pengaruh negatif. Dan variabel ini mempunyai tingkat signifikan dengan probability sebesar 0,000 yang apabila dibandingkan dengan derajat kesalahan yang telah di tentukan sebesar $5 \%$, variabel ini termasuk signifikan. Nilai signifikan variabel lebih kecil dari derajat kesalahan $(0,000<0,05)$ yang artinya bahwa hipotesis 0 ditolak dan $\mathrm{H} 2$ diterima. Dari hasil uji t disimpulkan bahwa Kurs Rupiah/Dolar Amerika berpengaruh negatif dan signifikan terhadap Indeks Harga Saham Gabungan (IHSG).

3. Pengujian Hipotesis Ketiga

Hasil analisis menunjukkan bahwa dapat diketahui Jumlah Uang Beredar menghasilkan nilai t-statistic sebesar 8.088446 bahwa jumlah uang beredar memiliki pengaruh positif.Variabel ini mempunyai tingkat signifikan sebesar 0,000 yang apabila dibandingkan dengan derajat kesalahan yang telah di tentukan sebesar 5\%, variabel ini termasuk signifikan. Nilai signifikan variabel lebih kecil dari derajat kesalahan $(0,000<0,05)$ yang artinya bahwa hipotesis 0 ditolak dan $\mathrm{H} 2$ diterima. Dari hasil uji t disimpulkan bahwa jumlah uang beredar berpengaruh positif dan signifikan terhadap indeks harga saham gabungan. 


\section{Hipotesis Secara Simultan (Uji F)}

Uji ini bertujuan untuk mengetahui apakah variabel bebas secara bersama-sama berpengaruh terhadap variabel terikat dan juga untuk mengetahui ketepatan pemilihan variabel yang akan dibentuk kedalam sebuah model regrasi maka dilakukan pengujian F-statistik. Hasil uji F dapat dilihat pada tabel dibawah ini :

\section{Tabel 4.9 \\ Hasil uji F-Statistik}

Dependent Variable: IHSG

Method: Least Squares

Date: 01/10/18 Time: $21: 36$

Sample: 160

Included observations: 60

R-squared
Adiusted R-squared
S-E. of regression
Sum squared resid
Log likelihood
F-statistic
Prob(F-statistic)

0.683076

0.666098

258.0133

3727967

$-416.2472$

40.23288

O.OOOOOO

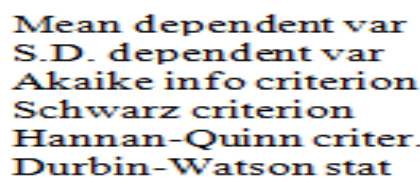

Durbin-Watson stat

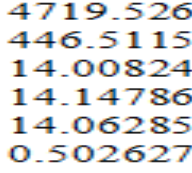

Berdasarkan tabel 4.9 diatas menunjukkan nilai F-statistik sebesar 40.23288 dan probability sebesar 0,000 dengan tingkat kesalahan yang digunakan sebesar 0,05. Hasil yang diperoleh menunjukkan bahwa nilai probability yang dihasilkan sebesar $0,000<0,05$ maka keputusannya adalah bahwa Inflasi, kurs Rupiah/Dolar Amerika, dan Jumlah Uang Beredar berpengaruh signifikan secara bersama-sama terhadap Indeks Harga Saham Gabungan (IHSG) di Bursa Efek Indonesia periode 2012-2016.

\section{Hasil Koefisien Determinasi $\left(\mathbf{R}^{2}\right)$}

Koefisien determinasi $\left(\mathrm{R}^{2}\right)$ menunjukkan proporsi yang diterangkan oleh variabel bebas dalam model terhadap variabel terikatnya, sisanya dijelaskann oleh variabel lain yang tidak dimasukkan dalam model, formulasi model yang keliru dan kesalahan eksperimen. Hasil uji koefisien determinasi dapat dilihat pada tabel dibawah ini :

\section{Tabel 4.10}

IFasil Uji Koefisien Determinasi $\left(R^{2}\right)$

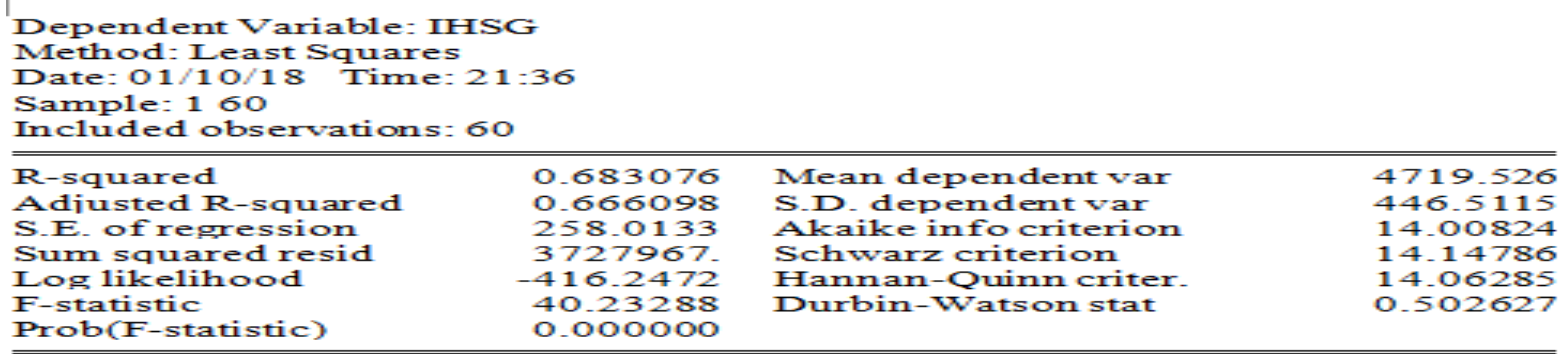

Berdasarkan Tabel 4.10 menunjukkan bahwa nilai koefisien determinasi yang dihasilkan dalam pengujian Adjusted $R$-squared bernilai 0.666. Hasil yang diperoleh menunjukkan bahwa Inflasi, Kurs Rupiah/Dolar Amerika dan Jumlah Uang Beredar mampu memberikan kontribusi dalam mempengaruhi IHSG sebesar $66,60 \%$ sedangkan sisanya 33,40\% lagi dipengaruhi oleh variabel lain diluar dari penelitian ini.

\section{Iterprestasi Penelitian}

Nilai dari uji t bahwa Inflasi menghasilkan nilai t-statistic sebesar 3,527339. Variabel ini mempunyai pengaruh positif dan tingkat signifikan dengan probability sebesar 0,0008 yang apabila dibandingkan dengan derajat kesalahan yang telah di tentukan sebesar 5\%, variabel ini termasuk signifikan. Nilai signifikan variabel lebih kecil dari derajat kesalahan $(0,0008<0,05)$ yang artinya 
bahwa hipotesis 0 ditolak dan $\mathrm{H} 2$ diterima. Dari hasil uji t disimpulkan bahwa inflasi berpengaruh positif dan signifikan terhadap Indeks Harga Saham Gabungan (IHSG).

Kurs Rupiah/Dolar Amerika menghasilkan nilai t-statistic sebesar -6.093663 bahwa kurs mempunyai pengaruh negatif. Dan variabel ini mempunyai tingkat signifikan dengan probability sebesar 0,000 yang apabila dibandingkan dengan derajat kesalahan yang telah di tentukan sebesar $5 \%$, variabel ini termasuk signifikan. Nilai signifikan variabel lebih kecil dari derajat kesalahan $(0,000<0,05)$ yang artinya bahwa hipotesis 0 ditolak dan $\mathrm{H} 2$ diterima. Dari hasil uji $\mathrm{t}$ disimpulkan bahwa Kurs Rupiah/Dolar Amerika berpengaruh negatif dan signifikan terhadap Indeks Harga Saham Gabungan (IHSG).

JUB (M2) menghasilkan nilai t-statistic sebesar 8.088446 bahwa jumlah uang beredar memiliki pengaruh positif.Variabel ini mempunyai tingkat signifikan dengan probability sebesar 0,000 yang apabila dibandingkan dengan derajat kesalahan yang telah di tentukan sebesar 5\%, variabel ini termasuk signifikan. Nilai signifikan variabel lebih kecil dari derajat kesalahan $(0,000<0,05)$ yang artinya bahwa hipotesis 0 ditolak dan $\mathrm{H} 2$ diterima. Dari hasil uji t disimpulkan bahwa jumlah uang beredar berpengaruh positif dan signifikan terhadap indeks harga saham gabungan.

Nilai F-statistik sebesar 40.23288 dan probability sebesar 0,000 dengan tingkat kesalahan yang digunakan sebesar 0,05 . Hasil yang diperoleh menunjukkan bahwa nilai probability yang dihasilkan sebesar 0,000 < 0,05 maka keputusannya adalah bahwa Inflasi, kurs Rupiah/Dolar Amerika, dan Jumlah Uang Beredar berpengaruh signifikan secara bersama-sama terhadap Indeks Harga Saham Gabungan (IHSG) di Bursa Efek Indonesia periode 2012-2016.

Koefisien determinasi atau Uji R yang dihasilkan dalam pengujian Adjusted $R$-squared bernilai 0.666. Hasil yang diperoleh menunjukkan bahwa Inflasi, Kurs Rupiah/Dolar Amerika dan Jumlah Uang Beredar mampu memberikan kontribusi dalam mempengaruhi IHSG sebesar 66,60\% sedangkan sisanya 33,40\% lagi dipengaruhi oleh variabel lain diluar dari penelitian ini.

\section{KESIMPULAN}

Penelitian ini bertujuan untuk menganalisis serta melihat sejauh mana Pengaruh Inflasi, Kurs Rupiah/Dolar Amerika dan Jumlah Uang Beredar terhadap Indeks Harga Saham Gabungan (IHSG) pada Bursa Efek Indonesia (BEI) Periode 2012-2016 berdasarkan hasil pengujian dan hipotesis yang telah dilakukan, serta melihat kembali dari pemaparan bab sebelumnya, maka penulis dapat membuat kesimpulan terhadap hasil penelitian ini sebagai berikut:

1. Variabel Inflasi secara parsial berpengaruh positif dan signifikan terhadap Indeks Harga Saham Gabungan di Bursa Efek Indonesia (BEI), hal ini dapat di buktikan dengan nilai t-statistic sebesar 3,527339 dan tingkat signifikan dengan nilai probability sebesar 0,0008<0,05 yang dapat dilihat pada table 4.8 hasil Uji t.

2. Variabel Kurs Rupiah/Dolar Amerika secara parsial berpengaruh negatif dan signifikan terhadap Indeks Harga Saham Gabungan di Bursa Efek Indonesia (BEI), hal ini dapat di buktikan dengan nilai t-statistic sebesar -6.093663 dan tingkat signifikan dengan nilai probability sebesar $0,000<0,05$ yang dapat dilihat pada table 4.8 hasil Uji t.

3. Variabel Jumlah Uang Beredar (M2) secara parsial berpengaruh positif terhadap Indeks Harga Saham Gabungan (IHSG) di Bursa Efek Indonesia (BEI), hal ini dapat di buktikan dengan nilai t-statistic sebesar 8.088446 dan tingkat sifinifikan dengan nilai probability sebesar $0,000<0,05$ yang dapat dilihat pada table 4.8 hasil Uji t.

4. Variabel Inflasi, Kurs Rupiah/Dolar Amerika, Jumlah Uang Beredar secara simultan berpengaruh positif terhadap Indeks Harga Saham Gabungan di Bursa Efek Indonesia (BEI), hal ini dapat di buktikan dengan nilai probability sebesar $0,000<0,05$ yang dapat dilihat pada table 4.9 hasil Uji f.

\section{DAFTAR PUSTAKA}

Ajaz, Taufeeq dkk (2016) Stock prices, exchange rate and interest rate: evidence beyo symmetry. School of Economics, University of Hyderabad, Hyderabad, India. The current issue and full 
text archive of this journal is available on Emerald Insight at :www.emeraldinsight.com/1757-6385.htm

Amin, Muhammad Zuhdi (2012) Pengaruh Tingkat Inflasi, Suku Bunga SBI, Nilai Kurs Dolar USD/IDR), dan Indeks Dow Jones (DJIA) Terhadap Pergerakan Indeks Harga Saham Gabungan Di Bursa Efek Indonesia (BEI) (PERIODE 2008-2011) Skripsi/Muhammad Zuhdi Amin/FEB UB/ 2012.

Appa, Yuni (2014) Pengaruh Inflasi Dan Kurs Rupiah/Dolar Amerika Terhadap Indeks Harga Saham Gabungan (IHSG) Di Bursa Efek Indonesia (BEI) eJournal Administrasi Bisnis, Volume 2, Nomor 4, 2014:498-512.

Astuti, Ria dkk (2013) Analisis Pengaruh Tingkat Suku Bunga (SBI), Nilai Tukar (KURS) Rupiah, Inflasi, dan Indeks Bursa Internasional Terhadap IHSG (Studi Pada IHSG Di BEI Periode 2008-2012) Diponegoro Journal Of Social And Politic Of Science Tahun 2013, Hal.18http://ejournal s1.undip.ac.id/index.php/

Fahmi, Irham.2013.“Rahasia Saham dan Obligasi”. Bandung:Alfabeta.

Febriyanto(2016) Pengaruh Nilai Indonesia Crude Price (ICP), Nilai Kurs Rupiah dan Sertifikat Bank Indonesia (SBI) terhadap Indeks Harga Saham Gabungan (IHSG) menjelang pemberlakuan MEA 2015. Dosen Fakultas Ekonomi Universitas Muhammadiyah Metro Jl. Ki Hajar Dewantara No. 116, Iringmulya Kota Metro 34111

Fildria, Liza (2014) Pengaruh Tingkat Inflasi Dan Kurs USA terhadap indeks Harga Saham Gabunganmtahun 2007 sampai 2011 (studi Kasus Dibursa Efek Indonesia)

Gossel, Sean J. and Nicholas Biekpe (2012) The nominal rand/dollar exchange rate: before and after 1995. Studies in Economics and Finance Vol. 29 No. 2, 2012 pp. 105-117 q Emerald Group Publishing Limited 1086-7376 Graduate School of Business, University of Cape Town, Cape Town, South Africa. The current issue and full text archive of this journal is available at www.emeraldinsight.com/1086-7376.htm

Hadi, sri ratna.2013. saham tanpa modal.Pt Niaga swadaya:jakarta

Hartono,Jogiyanto.2013.’Teori Portofolio Analisis Investasi Yogjakarta”: BPFE

Kasmir,Dr.2013.Bank dan Lembaga Keuangan Lainnya.jakarta:Pt Raja Grafindo Persada.

Kusharfitri, Diah Anggadewi(2016) Analisis Pengaruh Tingkat Suku Bunga, Inflasi dan Jumlah Uang Beredar (M2) Terhadap Indeks Harga Saham Gabungan Di Bursa Efek Indonesia Tahun 2009:05 - 2013: 12, Skripsi, Fakultas Ekonomi Pembangunan Dan Fakultas Hukum Ekonomi Syariah, Universitas Muhammadiyah Surakarta, 2016.

Kusuma, I Putu Marta Edi (2016) Pengaruh Inflasi, JUB, Nilai Kurs Dollar dan Pertumbuhan GDP Terhadap IHSG Di Bursa Efek Indonesia E-Jurnal Manajemen Unud, Vol.5, No. 3, 2016: 1829-1858 ISSN : 2302-8912

Lee, Koon Nam Henry (2016) Residential property price-stock price nexus in Hong Kong: new evidence from ARDL bounds test, City University of Hong Kong, Kowloon, Hong Kong The current issue and full text archive of this journal is available on Emerald Insight at: www.emeraldinsight.com/1753-8270.htm

Tandelilin, Edruardus 2013. "Portofolio dan Investasi Teori dan Aplikasi”. Yogyakarta: Kanisua

Umar, Muhammad and Gang Sun (2014) Country risk, stock prices, and the exchange rate of the renminbi School of Finance, Dongbei University of Finance \& Economics, Dalian, 